\title{
ANATOMY AND PALYNOLOGY OF SALVIA VERTICILLATA SUBSP. VERTICILLATA L. (LAMIACEAE), A RED-LISTED SPECIES IN TURKEY
}

\author{
Onur Koyuncu, Ismuhan Potoglu Erkara* and Murat Ardic \\ Department of Biology, Faculty of Science and Art, Eskişehir Osmangazi University, 26480, \\ Meselik, Eskisehir, Turkey
}

Key words: Salvia verticillata, Lamiaceae, Anatomy, Pollen morphology, Turkey

\begin{abstract}
Salvia verticillata L. subsp. verticillata has four cornered stem with 5-6 layers of collenchyma cells inside the epidermis. The pith is parenchymatous. In the leaf mesophyll, the palisade and spongy parenchyma cells were of similar shape. The leaf was amphistomatious. The plant was amaryllis mesomorphic and anisocytic type of stomata. The pollen grains were suboblate-subprolate and stephanocolpate. Exine was seen to be tectate-granulate.
\end{abstract}

The genus Salvia L. (Lamiaceae) consists of more than 900 species which are distributed all over the world (Standley and Williams 1987, Hedge 1992). Most of Salvia species are considered to be economically important for its essential oils (Özdemir and Senel 1999, 2001, Kandemir 2003, Özdemir and Altan 2005, Baran and Özdemir 2006). Glandular hairs found in all species of Salvia are responsible for the secretion of essential oils (Werker et al. 1985). But no detailed anatomical and palynological studies had been carried out earlier. Therefore, the present study was undertaken in order to give a detailed account of the anatomical and palynological characters of $S$. verticillata L. subsp. verticillata found in Turkey.

Salvia verticillata L. subsp. verticillata were collected from Geyve (Adapazari). A3 Sakarya: Kamışlı Village, Kamışl1-Kulfalar road, forest area, road sides, 40³3'35.6” N- 030²2’49.6” E, $597 \mathrm{~m}, 18.05 .2003$, OUFE: 12672. Herbaria were prepared and they were kept as voucher specimens at the Eskişehir Osmangazi University Herbarium (OUFE 12672). For the anatomical study, root, stem and leaf were fixed in $70 \%$ alcohol and hand sectioned. The pollen slides were examined which were prepared according to by Wodehouse (1935) and Erdtman (1969). Faegri and Iversen's (1975) terminology was used for the names of the exine layers. The exine and intine thickness was measured for a minimum of 20 samples

There is a periderm layer on the outer surface of the root. Parenchymatous cortex is present under the periderm. Phloem occupies a narrow area. Cambium cells are distinguishable. Pith region is narrow because of xylem that occupies much of the pith region (Fig. 1). Metcalfe and Chalk (1972) have shown collenchyma cells in each corner. They also stated that the rays may consist of 2-12 or more layers of cells in this family. In this study, it was discovered that these rays consist of 1-7 layered cells. Since the number of rays is different in every species, this can be used as an identifying character of the species. Similar observation has been reported in the root anatomy of Salvia sclarea, Salvia forskahlei, Salvia hypargeia, Salvia huberi and Salvia napifolia (Özdemir and Senel 1999, 2001, Kandemir 2003, Özdemir and Altan 2005, Baran and Özdemir 2006). The lignified cell walls in xylem can be seen particularly in S. sclarea, S. forskahlei, S. hypargeia, S. huberi and S. napifolia.

Stem is typically four-cornered and possesses a thick cuticle with small-celled epidermis. There are multicellular hairs on the epidermis and most of them are glandular. The glandular hairs

*Corresponding author. E-mail: ismuhan@ogu.edu.tr 
are capitate with distinct head. Cortex is 5-6-layered and parenchymatous. There is a 5-6-layered collenchymatous tissue. Dense collenchymatous cells located at the corners of the stem is a distinguishing anatomical characteristic of the family Lamiaceae. There is a sclerenchymatous sheath on the phloem tissue which occupies a small region. Cambium is not distinguishable and the pith region is large and parencymatic (Fig. 2). Under the epidermis, there are 5-6 cortex cell layers and below the 2-3 layers chlorenchyma are situated. The existence of chlorenchyma may be considered as a typical response to the photosynthetic ability of the stem. Thus, the effect of photosynthesis of the leaf and also the stem is increased (Fahn 1967). The typical four-cornered stem with dense collenchymatic cell walls located in the corners is a distinguishing anatomical characteristic of the family Lamiaceae (Fahn 1967, Metcalfe and Chalk 1972). The existence of the stem's parencymatic pith is observeable in the stem of S. sclarea, S. forskahlei, S. hypargeia,
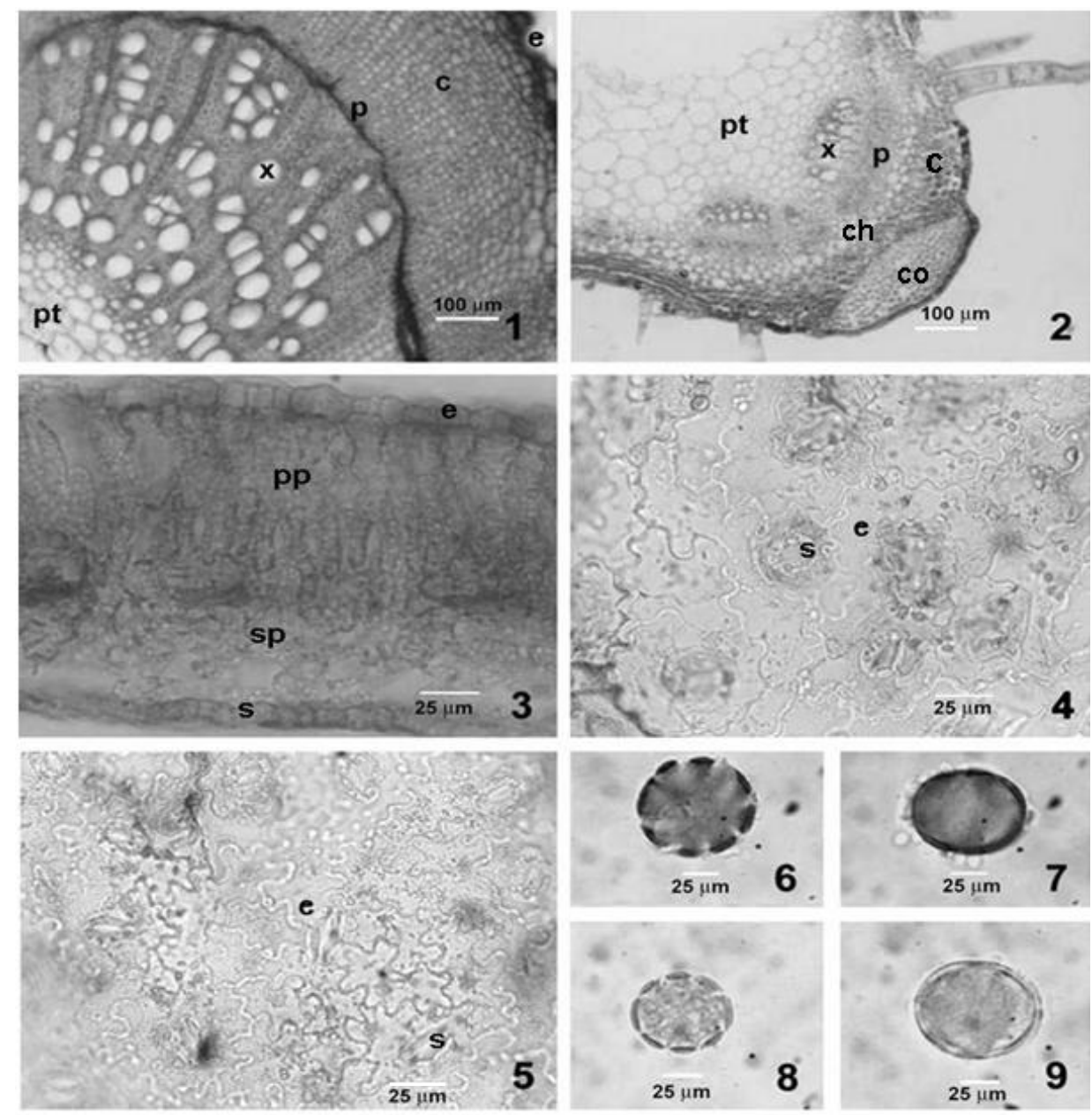

Figs. 1-9. Anatomy and pollen morphology of Salvia verticillata subsp. verticillata. 1. Cross-section of a root. 2. Cross-section of a stem. 3. cross-section of a leaf. 4. Upper surface of a leaf. 5. Lower surface of a leaf. 6. Polar view of a non acetolysed pollen. 7. Equatorial view of a non acetolysed pollen . 8. Polar view of an acetolysed pollen). 9. Equatorial view of an acetolysed pollen under light microscope. (Abbreviations: c: cortex, ch: chlorenchyma, co: collenchyma, e: epidermis, p: phloem, pp: palisade parenchyma, pt: pith, s: stomata, sp: spongy parenchyma, x: xylem). Scales: figs 1-2 $=100 \mu \mathrm{m}$, Figs 3-9 $=25 \mu \mathrm{m}$. 
S. huberi and S. napifolia (Özdemir and Senel 1999, 2001, Kandemir 2003, Özdemir and Altan 2005, Baran and Özdemir 2006). In leaves the upper epidermis consists of flat-ovoidal cells and the lower epidermis is made up of cells having same length and breadth. Stoma cells are present both in the upper and lower epidermis. Palisade parenchyma cells are two-layered. There are a lot of glandular and eglandular hairs on both upper and lower epidermis. Most of the glandular hairs were capitate and they had two head cells. The leaf is amphistomatic (Fig. 3). The plant has amaryllis mesomorphic and anisocytic type of stomata. In the leaf anatomy, epidermal cells of different sizes can be observed with larger epidermal cells occurring on the underside. The leaves are bifacial. The occurrence of the leaf being bifacial has been reported in S. sclarea, S. forskahlei, S. hypargeia, S. huberi and S. napifolia (Özdemir and Senel 1999, 2001, Kandemir 2003, Özdemir and Altan 2005, Baran and Özdemir 2006). There are amaryllis and anisosytic type of stomata on both surfaces of the leaf (Figs 4,5). Thus, the leaf is amphistomatic. Same has been reported in the leaves of S. sclarea, S. forskahlei, S. hypargeia, S. huberi and S. napifolia (Özdemir and Senel 1999, 2001, Kandemir 2003, Özdemir and Altan 2005, Baran and Özdemir 2006).

Table 1. Mean values of pollen morphometrical parameters of $S$. verticillata $\mathrm{L}$. subsp. verticillata having Non acetolysed (N) and Acetolysed (A) pollens.

\begin{tabular}{lccccccccc}
\hline Taxon & $\mathrm{P}$ & $\mathrm{E}$ & $\mathrm{P} / \mathrm{E}$ & $\mathrm{L}$ & $\mathrm{clg}$ & $\mathrm{clt}$ & $\mathrm{t}$ & Exine & intine \\
\hline \multirow{2}{*}{$\mathrm{N}$} & 32.5 & 32.35 & \multirow{2}{*}{1,00} & 26.92 & 20.9 & 7.25 & 7.28 & 1.29 & 0.48 \\
& \pm 3.03 & \pm 2.99 & & \pm 2.15 & \pm 2.96 & \pm 2.11 & \pm 2.49 & \pm 0.33 & \pm 0.19 \\
\multirow{2}{*}{$\mathrm{A}$} & 24.6 & 28.5 & \multirow{2}{*}{0,86} & 26.92 & 10.75 & 5.5 & 5.29 & 1.20 & - \\
& \pm 2.88 & \pm 1.71 & & \pm 2.15 & \pm 1.53 & \pm 1.71 & \pm 2.11 & \pm 0.38 & - \\
\hline
\end{tabular}

P, Polar axis; E, Equatorial axis; L, Equatorial countour diameter; t, Apocolpium; clg, Length of the colpus; clt, Width of the colpus.

Pollens of Salvia verticillata L. subsp. verticillata are suboblate-subprolate and stephanocolpatae, $\mathrm{P} / \mathrm{E}=1.00(\mathrm{~N}), 0.86(\mathrm{~A})$. Ornamentation is tectate-granulate. Exine $1.29 \mu \mathrm{m}(\mathrm{N})$, $1.20 \mu \mathrm{m}$ (A), (Figs 6-9, Table 1). The light microscopic investigation revealed suboblatesubprolate and stephanocolpate pollen grains in Salvia verticillata L. subsp. verticillata. Exine is tectate-granulate. The morphological features of exine layers have been reported to be the features that best explain the nature of the phylogenetic relationship among the various taxa (Cronquist 1968, Walker 1974a,b, Takhtajan 1980). Thus, difference in pollen morphology and anatomical structures of the taxon could be a reflection of its genetic difference.

\section{References}

Baran P. and C. Özdemir. 2006. The morphological and anatomical characters of Salvia napifolia Jacq. in Turkey. Bangladesh J. Bot. 35(1): 77-84.

Cronquist A. 1968. The evolution and classification of the flowering plants. Thomas Nelson Ltd. Edinburgh.

Erdtman G. 1969. Handbook of palynology morphology, taxonomy, ecology. An Introduction to the Study of Pollen Grains and Spores. Hafner Pub. New York.

Faegri K. and J. Iversen. 1975. Textbook of pollen analysis. $3^{\text {rd }}$ edition. Munksgaard, Copenhagen, 295 pp.

Fahn A. 1967. Plant Anatomy, Pergamon Press, New York, 534 pp.

Hedge I.C. 1992. A global survey of the Labiatae. In: Advances in Labiatae Science, R.M. Harley \& T. Reynolds (Eds), pp. 7-18. Royal Botanic Gardens, Kew.

Kandemir N. 2003. The morphological, anatomical and caryological properties of endemic Salvia hypargeia Fich. \& Mey. (Lamiaceae) in Turkey. Pak. J. Bot. 35(2): 219-236.

Metcalfe CR. and L. Chalk. 1972. Anatomy of Dicotyledons 2: pp. 1041-1053. Clarendon Press, Oxford. 
Ozdemir C. and G. Senel. 1999. The morphological, anatomical and karyological properties of Salvia sclarea L. Tr. J. Bot. 23: 7-18.

Ozdemir C. and G. Senel. 2001. The morphological, anatomical and karyological properties of Salvia forskahlei L. (Lamiaceae) in Turkey. J. Econ. \& Taxon. Bot. 19: 297-313.

Ozdemir C. and Y. Altan. 2005. Morphological and anatomical characteristics of endemic Salvia huberi Hedge in Turkey. Bangladesh J. Bot. 34(2): 95-100.

Standley P. and L. Williams. 1987. Labiatae. Fieldiana Bot. 24: 237-317.

Takhtajan A.L. 1980. Outline of the classification of flowering plants (Magnoliophyta). Bot. Rev. 46: 225-359.

Walker J.W. 1974a. Evolution of exine structure in the pollen of primitive Angiosperms. Amer. J. Bot. 61: 891-902.

Walker J.W. 1974b. Aperture evolution in the pollen of primitive Angiosperms. Amer. J. Bot. 61: 1112-1137.

Werker E., U. Ravid and Y. Putievsk. 1985. Structure of glandular hairs and identification of the main components of the their secreted material in some species of the Labiatae. Israel J. Bot. 34: 31-45.

Wodehouse R.P. 1935. Pollen Grains. McGraw Hill, New York. 574 pp.

(Manuscript received on 5 January, 2009; revised on 28 October, 2009) 